\title{
Effect of pyraclostrobin on mulberry leaves nutrients, silkworm cocoon production and silk fiber performance
}

\author{
Saulo Rocha Ferreira ${ }^{1}$, Luiz Eduardo Silva ${ }^{4}$, Renata Daniel dos Santos ${ }^{2}$, \\ Romildo Toledo Filho ${ }^{2}$, Otavio Fonseca Martins Gomes ${ }^{3}$, \\ Gustavo Henrique Denzin Tonoli ${ }^{4}$, Daniel Nicodemo ${ }^{5}$
}

\footnotetext{
${ }^{1}$ Departamento de Engenharia, Universidade Federal de Lavras, Campus Universitário, CP. 3037, CEP: 37200-000, Lavras, MG, Brasil.

2 Departamento de Engenharia Civil, COPPE/Universidade Federal do Rio de Janeiro, Centro de Tecnologia, Bloco I Sala 216, CP. 68506, CEP: 21941-972, Rio de Janeiro, RJ, Brasil.

${ }^{3}$ CETEM - Centro de Tecnologia Mineral, CEP: 21941-908, Rio de Janeiro, RJ, Brasil./ National Museum, Federal University of Rio de Janeiro, Av. Quinta da Boa Vista, S/N, Bairro Imperial de São Cristóvão, 20940-040, Rio de Janeiro, RJ, Brazil.

${ }^{4}$ Departamento de Ciências Florestais, Universidade Federal de Lavras, Campus Universitário, CP. 3037, CEP: 37200 000, Lavras, MG, Brasil.

${ }^{5}$ Universidade Estadual Paulista (UNESP), Faculdade de Ciências Agrárias e Tecnológicas, Campus de Dracena, Rod. Comandante João Ribeiro de Barros, Km 651, CEP 17900-000 Dracena, SP, Brasil.

e-mail: saulo.ferreira@deg.ufla.br, lesilvaflorestal@gmail.com, renatadaniel@poli.ufrj.br, ogomes@cetem.gov.br, rdtoledofilho@gmail.com, gustavotonoli@yahoo.com.br.
}

\begin{abstract}
The present work evaluates the effect of pyraclostrobin fungicide on the nutritional quality of mulberry leaves, silkworm cocoon production and silk fiber mechanical performance. The evaluation was performed in two consecutive years. In Spring 2015, mulberry plants were treated twice with 4 doses of pyraclostrobin $(0$, 100, 200, and 300 g.ha $^{-1}$ ), 30 and 15 days before pruning of the branches. In Spring 2016, the same plants received the same doses of pyraclostrobin only 30 days before pruning of the branches. Fifth instar caterpillars were fed on treated mulberry leaves. The mineral content of mulberry leaves was determined on pruning day of the branches and 30 days before. The consumption of mulberry leaves and the mortality rate of the caterpillars fed with the treated leaves was verified, and the cocoons obtained were classified and weighed. Silk fibers were submitted to mechanical evaluation by tensile test. Morphological and physical modification were evaluated by Scanning Electron Microscope (SEM) and X-ray diffraction (XRD). In 2015, the mortality of caterpillars fed on leaves treated with pyraclostrobin was at least 26.7\% higher than the control. At 2016 even with a single application the weight of the cocoons was lower. The main variation in the mineral content was observed in Mn and Fe nutrients. Mineral intake had a noticeable effect in both crystallinity and tensile strength. Results show that the use of pyraclostrobin may reduce the mechanical behavior of silk thread up to $70 \%$, indicating that its use is not indicated for mulberry planting aiming silk feeding.
\end{abstract}

Keywords: Bombyx mori. silk fibers. mulberry leaves. fibroin changes. Silkworm mortality, fiber performance

\section{INTRODUCTION}

Sericulture is an important agro-industrial activity in Brazil, which is the fourth largest producer of green cocoons and silk fibers [1, 2]. The Brazilian silk production is mostly destined to exportation due its excellent quality [2]. The silk quality can be correlated to mulberry (Morus spp.) cultivation processes, such as climatic conditions, spacing of cultivation, water availability for the plants, soil types, branches pruning, leaf growth, among others $[\underline{3}, \underline{4}]$.

The silkworm (Bombyx mori) diet is another important variable to be considered to obtain good quality silk. These insects need fresh food which should be offered three or more times a day as a condition for good quality silk fiber. The 
silkworm feed exclusively on mulberry leaves where it gets water and all the necessary nutrients for their development [2, 5].

As the nutrition of silkworm is a key parameter to improve silk quality, many studies are being carried out, aiming to enrich the diet of the silkworm, resulting in better quality fibers [6-9]. These studies focused on artificial diet pretreatment with graphene, hormone compounds and nanoparticles diets [10-12]. According to WANG et al. [13] the use of carbon nanotubes on silkworm diet increased the mechanical strength of silk in about $37 \%$.

The application of artificial diet with $\mathrm{TiO}_{2}$ nanoparticles led to direct production of intrinsically modified silk, increasing the strength and toughness of the silk [10]. WANG et al. [12] fed silkworm caterpillars with single-walled carbon nanotubes (SWNTs) and graphene. In this case, parts of the fed carbon nanomaterials were incorporated into the asspun silk fibers, which promoted the reinforcement of silk threads.

Several diets using mulberry leaves were evaluated by FERNANDES et al. [14]. In their work, different doses of Bordeaux mixture $(\mathrm{Bm})$, a traditional agricultural fungicide, were applied to silkworm diet, implying an increase in consumption of calcium oxide and copper sulphate by caterpillars. The results indicate that tensile strength of silk fibers presented an increase $(60 \%)$ after the use of $\mathrm{Bm}$ in silkworm diet.

Pyraclostrobin is a synthetic fungicide that belongs to the group of strobilurins and has translaminar and mesosystemic actions in plants [15]. This pesticide is used in many agricultural crops to reduce the occurrence of fungal diseases and its use also contributes to the increase of the photosynthetic rate and decrease of the cellular respiration, delaying the senescence of the treated plants [16-18]. These effects could be very interesting for the mulberry plants and consequently for the quality of silk threads. The objective of this study was to evaluate the treatment of mulberry plants with pyraclostrobin regarding the effect of this fungicide on the quality of silk thread spun by silkworm caterpillars.

\section{METHODOLOGY}

The treatments and silk production was performed in the city of Dracena, São Paulo state, Brazil, which is located at latitude 21 $27^{\prime} 37^{\prime}$ 'S and longitude 51'33'21'O, and has an altitude of $421 \mathrm{~m}$. The study was performed in 2015 and 2016 Spring at south hemisphere, between the months of September and November.

\subsection{Cultivation of mulberry plants and the treatment with pyraclostrobin}

Mulberry (Morus spp.) plants from cultivar IZ56/4 with a stand of 10.000 plants per hectare were used as food source for silkworm caterpillars.

The mulberry plants were treated with Comet BASF, a commercial fungicide whose active ingredient (a.i.) is pyraclostrobin. Four doses (0, 100, 200, and $300 \mathrm{~g} \mathrm{ha}^{-1}$ of a.i.), hereby Control, P100, P200 and P300, were used in 1.000 liters of aqueous spray per hectare which was applied uniformly on all leaves of mulberry plants, 30 and 15 days before branch pruning on Spring 2015. Based on the previously observation on 2015 results, the experiment performed on Spring 2016 used only a single application of the fungicide, 30 days before branch pruning (DBP).

In the control area plants, spray applications were made with water only. The leaves of these mulberry plants were offered to the caterpillars from 15 days after the last treatment with pyraclostrobin in 2015 and from 30 days after the single application of pyraclostrobin. For all the treatments, the interval between prunings of mulberry branches was 90 days.

A randomized block design was used: a block was considered an area of $200 \mathrm{~m}^{2}$ of mulberry plants, which was subdivided into four subareas, with each being treated with the corresponding dose of fungicide with four replications, totaling 16 groups of plants.

\subsection{Analysis of mineral content in mulberry leaves}

The macronutrient and micronutrient contents were analyzed from mulberry leaves at 60 and 90 (the day they were fed to the caterpillars) days after pruning (DAP), with samples containing 20 leaves [19]. After harvesting, the petioles were discarded, and the leaves were placed in identified paper bags, which were kept in an oven at $55^{\circ} \mathrm{C}$ for four days.

The variation of each mineral in the leaves at 90 DAP was calculated in percentage, considering the initial analysis at 60 DAP. The Nitrogen content was verified by the Kjeldahl method and estimated the crude protein content of the leaves [20, 21]. Phosphorus, Potassium, Calcium, Magnesium, Copper, Iron, Manganese and Zinc were extracted by dry route and Sulfur content by wet route [22]. Boron content was verified using the azomethine-H method [19].

\subsection{Silkworm rearing and cocoon production}

Third-instar silkworm caterpillars were obtained from Bratac Silk Industry. The caterpillars were reared in a $40 \mathrm{~m}^{2}$ room with controlled temperature $\left(26 \pm 2^{\circ} \mathrm{C}\right)$ and controlled relative humidity $(70 \pm 10 \%)$. 
The harvest of the mulberry branches was held daily in the early morning and late afternoon. In the third and fourth instars, the caterpillars were fed ad libitum with leaves from plants not treated with COMET. From the fourth ecdysis, before each of the three feeding periods (7:00 a.m., 1:00 p.m., and 7:00 p.m.), the leaves of the plants treated with pyraclostrobin were removed from the branches and the petioles were discarded. Then the leaves were weighed, and equal amounts of leaves were offered to the caterpillars of the respective treatments.

Groups of 300 individuals were fed with leaves from each subareas of each block with mulberry plants [23]. The consumption of mulberry leaves was verified in the 16 groups of caterpillars ( 4 blocks x 4 treatments) with 300 individuals each during the fifth instar of the caterpillars. For this evaluation, the total amount of feed provided for each group and the dry matter content of these leaves were considered.

Leaf litter (dry uneaten leaves) were discarded at the end of the fifth instar then dried in an oven to determine dry content [ $[$ ]. At the end of the fifth instar, live caterpillars in each group were counted and the mortality rate percentage was established based on the number of caterpillars present at the beginning of that instar.

At the end of the feeding period, management was carried out to the silkworm cocooning into an appropriate cardboard frame [2]. The cocoons were harvested on the eighth day after the formation of the first cocoon.

All cocoons obtained were evaluated for nonconformities, aiming to determine the percentage of declassified cocoons. All fresh cocoons obtained were weighed. The defective cocoons were separated and weighed again. The percentage of declassified cocoons per group was determined from the following equation (Eq.1):

(weight of declassified cocoons / weight of all cocoons produced) $\mathrm{x} 100$

To determine the crude silk content (CSC), 90 green cocoons without defect were weighed, determining the weight of the cocoons. Then, the cocoons were cut for the removal of the pupae and spoils, and weighed again, obtaining the weight of the cocoon shells. The CSC, with three replicates, was calculated from the following equation (Eq.2):

$\operatorname{CSC}(\%)=($ weight of 30 cocoons shells / weight of 30 cocoons $) \times 100$

To obtain the net silk content (NSC), the CSC value was multiplied by 0.76 [24].

\subsection{Silk fibers Characterization}

\subsubsection{X-ray diffraction (XRD)}

X-ray diffraction experiments were performed using an Eco D8 Advance X-ray diffractometer (Bruker) in a $2 \theta$ range from $10^{\circ}$ to $40^{\circ}$ by the method FT (fixed time). Used steps were equal to $0.01^{\circ}$, using a tube voltage and current equal to $30 \mathrm{kV}$ and $15 \mathrm{~mA}$, respectively. The radiation used was $\mathrm{CuK} \alpha=1.5418 \AA$ A. A polymethyl methacrylate (PMMA) sample holder was used. The test was performed in Centro de Tecnologia Mineral (CETEM), Rio de Janeiro.

\subsubsection{Scanning eléctron microscopy (SEM)}

The morphology and fracture mode of the silk fibers was determined using a scanning electron microscope JEOL model JSM-5300 (Jeol Ltd, Tokyo, Japan). The micrographs of natural and modified silk fibers were taken from samples fixed with carbon adhesive tape using a voltage acceleration of $25 \mathrm{kV}$ and working distance of $3 \mathrm{~mm}$. All samples were analyzed without coating. No tilt was applied. The test was performed in the Microlab of NUMATS/COPPE/UFRJ.

\subsubsection{Direct tensile test}

The control (reference with no treatment) and treated silk fibers were tested, in a laboratory condition, under tensile loading at a gage length (GL) of $20 \mathrm{~mm}$. For each treatment 15 tests were conducted on a microforce testing system (Tytron 250, MTS Systems, Minneapolis, MN, U.S.A.) (Figure 1a). A steel flat shaped mechanical clamping grip was used to grip the fibers (Figure 1b). The preparation of the specimen was performed according to ASTM C1557 [25]. A $25 \mathrm{~N}$ load cell with a resolution of $0.001 \mathrm{~N}$ was used to measured load. The test was performed in the Microlab of NUMATS/COPPE/UFRJ 
(a)

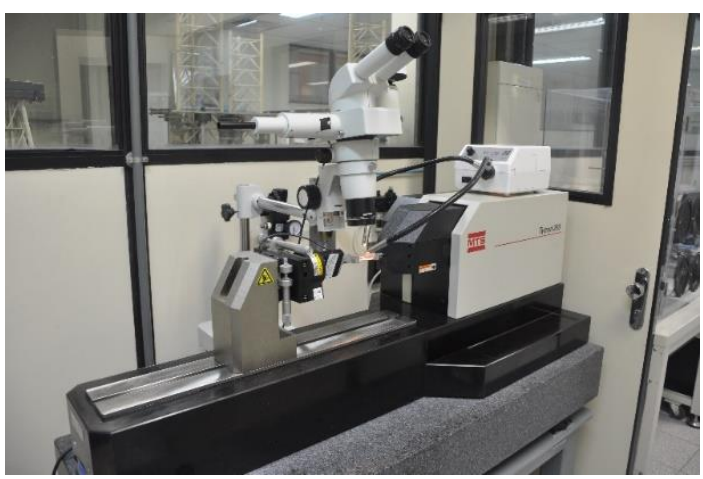

(b)

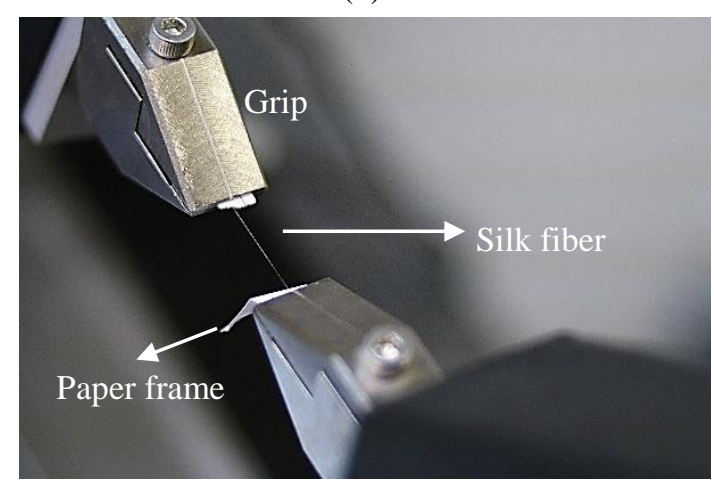

Figure 1. The tensile test system: (a) overall view of the microtesting machine coupled with a stereomicroscope. The microscope was used to check the fiber alignment and possible defects in the fiber. (b) Close up view in the fiber showing how it was fixed in the clamps. The paper frame was cut before the test.

The displacement of the fiber was measured using a short-stroke transducer with a resolution of about $0.1 \mu \mathrm{m}$. Tensile tests were conducted in displacement control at a rate of $0.5 \mathrm{~mm} / \mathrm{min}$. This displacement rate corresponded to a nominal strain rate, in the linear region of the stress-strain curve, of about $0.00008 \mathrm{~s}^{-1}$. All testing was conducted at ambient temperature $\left(22^{\circ} \mathrm{C}\right)$ and a relative humidity of about $65 \%$.

The Young's modulus was calculated at three different zones of the stress-strain curve: (I) the linear-elastic portion of the curve, (II) transition of linearity to non-linearity and (III) the non-linear region. This behavior was observed by FERREIRA et al. [26] for all coir fibers.

The fiber's microstructure, before and after fracture, was investigated using a scanning electron microscope following the procedure described before. To measure the fiber's cross-sectional area an adjacent piece of the fiber (immediately next to the one tested) was kept for further measurement using the SEM. The obtained images were post-processed using ImageJ (National Institutes of Health, Bethesda, Maryland, U.S.A.). A contour line was drawn to delineate the fiber cross-section and the area was computed.

\section{3. RESULTS AND DISCUSSION}

The results and discussion are presented in two sections: Spring 2015 and 2016 results.

\section{SPRING 2015}

\section{3.1. MINERAL CONTENT OF MULBERRY LEAVES}

The application of pyraclostrobin resulted in lower losses of nitrogen, phosphorus, potassium, copper, iron and zinc (Tables 1 and 2). For calcium and magnesium, apparently, there was no difference between the treated and control groups. The sulfur content decreased in the period evaluated in the leaves of control plants, however, it increased with the use of pyraclostrobin. Boron content in mulberry leaves increased in all groups, especially those treated with pyraclostrobin and while the manganese content in the leaves of control plants decreased, there was an increase in the content of this micronutrient in leaves treated with pyraclostrobin. 
Table 1: Mulberry leaves macronutrients contents $(\mathrm{g} / \mathrm{kg}$ of dry matter) and differences $(\Delta \%)$ between two evaluation periods of plants, in Spring 2015.

\begin{tabular}{|c|c|c|c|c|c|c|}
\hline \multicolumn{4}{|c|}{$\mathrm{N}(\mathrm{g} / \mathrm{kg})$} & \multicolumn{3}{|c|}{$\mathrm{P}(\mathrm{g} / \mathrm{kg})$} \\
\hline & $30 \mathrm{DBP}^{*}$ & Pruning day & $\Delta \%$ & 30 DBP & Pruning day & $\Delta \%$ \\
\hline Control & 44.0 & 37.3 & -15.2 & 3.6 & 2.6 & -27.1 \\
\hline $\mathrm{P} 100$ & 40.0 & 38.5 & -3.7 & 3.7 & 3.3 & -9.3 \\
\hline P200 & 40.8 & 39.9 & -2.4 & 3.8 & 3.3 & -12.8 \\
\hline P300 & 40.6 & 39.2 & -3.5 & 3.8 & 3.2 & -15.8 \\
\hline \multicolumn{4}{|c|}{$\mathrm{K}(\mathrm{g} / \mathrm{kg})$} & \multicolumn{3}{|c|}{$\mathrm{Ca}(\mathrm{g} / \mathrm{kg})$} \\
\hline & $30 \mathrm{DBP}$ & Pruning day & $\Delta \%$ & $30 \mathrm{DBP}$ & Pruning day & $\Delta \%$ \\
\hline Control & 21.3 & 18.9 & -11.2 & 20.3 & 30.8 & +51.4 \\
\hline P100 & 21.8 & 20.4 & -6.3 & 17.6 & 27.4 & +55.5 \\
\hline P200 & 22.0 & 20.4 & -7.4 & 19.5 & 27.1 & +39.1 \\
\hline \multirow[t]{3}{*}{ P300 } & 21.3 & 20.1 & -5.3 & 18.0 & 29.0 & +61.4 \\
\hline & \multicolumn{3}{|c|}{$\mathrm{Mg}(\mathrm{g} / \mathrm{kg})$} & \multicolumn{3}{|c|}{$\mathrm{S}(\mathrm{g} / \mathrm{kg})$} \\
\hline & 30 DBP & Pruning day & $\Delta \%$ & $30 \mathrm{DBP}$ & Pruning day & $\Delta \%$ \\
\hline Control & 3.4 & 3.6 & +5.7 & 2.7 & 2.2 & -17.4 \\
\hline P100 & 3.0 & 3.3 & +10.7 & 2.3 & 2.3 & +1.5 \\
\hline P200 & 3.1 & 3.2 & +5.5 & 2.3 & 2.6 & +9.2 \\
\hline $\mathrm{P} 300$ & 2.9 & 3.4 & +15.2 & 2.3 & 2.3 & +0.1 \\
\hline
\end{tabular}

*DBP $=$ days before pruning of mulberry branches

Table 2: Mulberry leaves micronutrients contents $(\mathrm{mg} / \mathrm{kg}$ of dry matter) and differences $(\Delta \%)$ between two evaluation periods of plants, in Spring 2015.

\begin{tabular}{|c|c|c|c|c|c|c|}
\hline & \multicolumn{3}{|c|}{$\mathrm{B}(\mathrm{mg} / \mathrm{kg})$} & \multicolumn{3}{|c|}{$\mathrm{Cu}(\mathrm{mg} / \mathrm{kg})$} \\
\hline & $30 \mathrm{DBP}^{*}$ & Pruning day & $\Delta \%$ & $30 \mathrm{DBP}$ & Pruning day & $\Delta \%$ \\
\hline Control & 36.7 & 52.4 & +43.0 & 5.0 & 3.9 & -22.5 \\
\hline P100 & 35.9 & 56.2 & +56.4 & 5.5 & 4.9 & -11.4 \\
\hline P200 & 37.5 & 58.2 & +55.2 & 4.5 & 4.5 & 0.0 \\
\hline P300 & 33.0 & 57.8 & +75.4 & 5.0 & 4.8 & -5.0 \\
\hline & \multicolumn{3}{|c|}{$\mathrm{Fe}(\mathrm{mg} / \mathrm{kg})$} & & \multicolumn{2}{|c|}{$\mathrm{Mn}(\mathrm{mg} / \mathrm{kg})$} \\
\hline & 30 DBP & Pruning day & $\Delta \%$ & $30 \mathrm{DBP}$ & Pruning day & $\Delta \%$ \\
\hline Control & 196.0 & 116.5 & -40.6 & 46.0 & 44.0 & -4.3 \\
\hline $\mathrm{P} 100$ & 185.0 & 121.3 & -34.5 & 53.5 & 70.3 & +31.3 \\
\hline $\mathrm{P} 200$ & 171.0 & 128.0 & -25.1 & 44.0 & 53.8 & +22.2 \\
\hline P300 & 155.0 & 116.0 & -25.2 & 37.5 & 48.3 & +28.7 \\
\hline
\end{tabular}

*DAP $=$ days after pruning

\subsubsection{MULBERRY LEAVES CONSUMPTION, SILKWORM MORTALITY AND COCOON PRODUCTION}

Mulberry leaves consumption per caterpillar was not different between the groups evaluated ( $p>0.20)$, but mortality increased considerably with the use of pyraclostrobin, evidencing a dose-dependent effect (Table 3). Caterpillar mortality levels exceeding $10 \%$ undermine financial viability of cocoon production [2]. According to the results it is possible to observe that pyraclostrobin has promoted the death of more than $10 \%$ of the caterpillars, even with the lowest doses. 
Table 3: Consumption in grams (g) of dry matter of mulberry leaves per caterpillar in the fifth instar and mortality rate (\%) in the Spring of 2015.

\begin{tabular}{ccc}
\hline Treatments & Consumption $(\mathrm{g})$ & Mortality (\%) \\
\hline Control & $5.44 \pm 1.34$ & $8.65 \pm 1.47$ \\
P100 & $6.24 \pm 2.16$ & $10.96 \pm 3.99$ \\
P200 & $5.07 \pm 0.95$ & $25.70 \pm 4.37$ \\
P300 & $5.74 \pm 1.46$ & $56.40 \pm 3.81$ \\
\hline
\end{tabular}

The heavier cocoons were obtained when the caterpillars received leaves not treated with pyraclostrobin. The production of cocoons was significantly impaired due to the use of pyraclostrobin, and a dose-dependent negative effect was observed (Table 4).

Table 4: Weight of cocoons and cocoon shells (g), crude silk content (CSC,\%), net silk content (NSC,\%) and percentage of defective cocoons obtained from caterpillars fed on leaves treated with pyraclostrobin in the Spring of 2015.

\begin{tabular}{cccccc}
\hline Treatments & Cocoons $(\mathbf{g})$ & $\begin{array}{c}\text { Cocoon shells } \\
(\mathbf{g})\end{array}$ & $\begin{array}{c}\text { CSC } \\
(\%)\end{array}$ & $\begin{array}{c}\text { NSC } \\
(\%)\end{array}$ & $\begin{array}{c}\text { Declassified } \\
\text { cocoons (\%) }\end{array}$ \\
\hline Control & $1.86 \pm 0.18 \mathrm{a}^{1}$ & $0.45 \pm 0.03 \mathrm{a}$ & $24.13 \pm 1.42$ & $18.34 \pm 1.07$ & 3.00 \\
P100 & $1.74 \pm 0.18 \mathrm{~b}$ & $0.41 \pm 0.02 \mathrm{~b}$ & $23.76 \pm 1.09$ & $18.06 \pm 0.83$ & 3.10 \\
P200 & $1.69 \pm 0.20 \mathrm{c}$ & $0.40 \pm 0.03 \mathrm{c}$ & $23.71 \pm 0.99$ & $18.02 \pm 0.75$ & 4.50 \\
P300 & $1.45 \pm 0.20 \mathrm{~d}$ & $0.35 \pm 0.04 \mathrm{~d}$ & $24.12 \pm 1.38$ & $18.33 \pm 1.05$ & 5.70 \\
\hline
\end{tabular}

${ }^{1}$ Means followed by different letters in the same column differ by the Tukey test (5\%).

The X-ray diffractograms of silk fiber threads in different conditions are presented in Figure 2. Crystallinity and crystal size values are presented in Table 5. The three peaks denoted in the diffractogram represent Silk II, whereas the smooth peak located between peaks two and three corresponds to Silk I. No difference regarding Silk I was observed between the treatments. Silk I is in a granular state prior to crystallization and is easily converted to Silk II, which consists of beta-sheet secondary structure, in the spinning process. The difference between silk polymorphs correspond to the chain structure produced. While Silk I is a water-soluble material, and its conversion to Silk II is caused by heat exposure or physical spinning, creating a more thermodynamically stable thread [27].The indication of Silk I on Figure 2 represents the area where the peak usually is shown. The treatments have a direct correlation to nutrients absorption which can modify the rheology as well as the conformation of the fibroin being produced. It is known that certain minerals can facilitate the transition from Silk I to Silk II like $\mathrm{Cu}$ and $\mathrm{Ca}[\underline{6}, 14]$. Other minerals, however, like Mn can hinder the formation of beta-sheet secondary structures which promote the maintenance of Silk I during the spinning process [28]. Even though all treatments presented higher concentrations of $\mathrm{Mn}$, they also have more $\mathrm{Cu}$ and $\mathrm{Ca}$ being fed to them (Tables 1 and 2). This change in nutrition may cause an increase in the crystallinity in P200 compared to the control, as well as facilitated the conversion from Silk I to Silk II. The fact that Silk is a semi-crystalline material may have difficulted the visualization of Silk I peaks, which could be overlapped by the presence of amorphous counterparts. 
Spring 2015

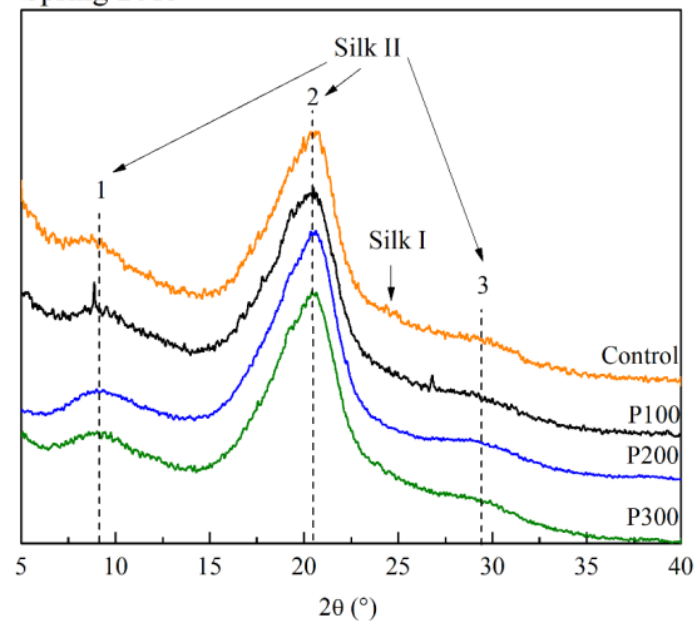

Figure 2: X-ray diffractograms of silk fibers thread produced in Spring of 2015, in different conditions. Peaks 1, 2 and 3 are related to Silk II, while the smooth peak between peaks 2 and 3 corresponds to Silk I.

Table 5: Crystallinity parameters determined from the X-ray diffractograms of silk fiber in different conditions at Spring 2015

\begin{tabular}{cccc}
\hline Fibers/Treatment & Crystallinity (\%) & Peak & Crystal size (nm) \\
\hline Control & 65.0 & 1 & 2.3 \\
& & 2 & 3.6 \\
P100 & 63.6 & 1 & 2.3 \\
P200 & & 2 & 3.3 \\
& 67.7 & 1 & 2.2 \\
P300 & & 2 & 4.1 \\
& 61.8 & 1 & 2.1 \\
\hline
\end{tabular}

The comparison between the typical curves obtained by tensile test of silk fibers from Spring of 2015 is presented in Figure 3. Table 6 summarizes the results for all mechanical tests. When comparing the treatments, it is possible to observe that the treatment P100, P200 and P300 promoted a decrease in the ultimate tensile strength (around 50\%), when compared to control treatment. The same reduction was observed to tensile strain. 


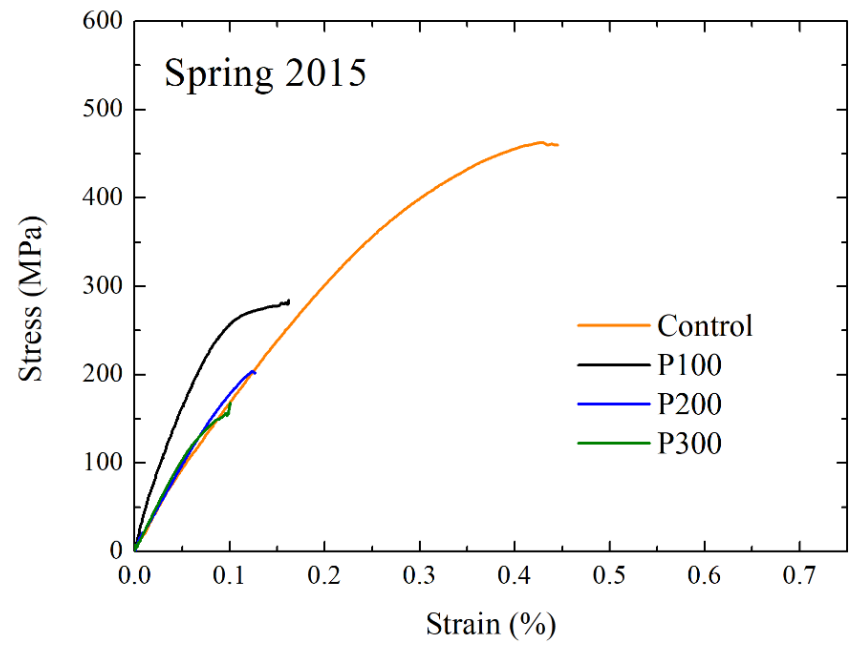

Figure 3. Typical curve from silk fibers of Spring 2015 with treatments P100, P200, P300 and Control.

Table 6: Mechanical properties of natural fibers on tensile strength tested on Spring 2015

\begin{tabular}{cccccc}
\hline Fibers & & Control & P100 & P200 & P300 \\
\hline Strain & $(\%)$ & $0.48 \pm 0.14$ & $0.13 \pm 0.04$ & $0.13 \pm 0.04$ & $0.13 \pm 0.03$ \\
Tensile Strength & $(\mathrm{MPa})$ & $497.5 \pm 47.8$ & $285.0 \pm 58.5$ & $180.1 \pm 48.4$ & $150.4 \pm 31.4$ \\
Young modulus I & $(\mathrm{GPa})$ & $4.8 \pm 1.1$ & $5.5 \pm 0.4$ & $5.4 \pm 0.2$ & $5.2 \pm 0.1$ \\
Young modulus II & $(\mathrm{GPa})$ & $5.7 \pm 0.5$ & $*$ & $*$ & $*$ \\
Young modulus III & $(\mathrm{GPa})$ & $5.1 \pm 1.2$ & $*$ & $*$ & $*$ \\
Resilience & $(\mathrm{MPa})$ & $1.47 \pm 0.63$ & $2.22 \pm 1.45$ & $1.21 \pm 0.43$ & $0.70 \pm 0.38$ \\
Toughness & $\left(\mathrm{J} / \mathrm{m}^{2}\right)$ & $29.29 \pm 11.54$ & $3.78 \pm 2.19$ & $1.85 \pm 0.94$ & $1.45 \pm 0.70$ \\
\hline *fiber rupture & & & &
\end{tabular}

The rupture mode of all tested silk fibers is presented in Figure 4. Is possible to observe that all fibers presented the same rupture mode. Regarding the fiber cross-section, no significant difference in cross-section area was observed. 


\section{Control}

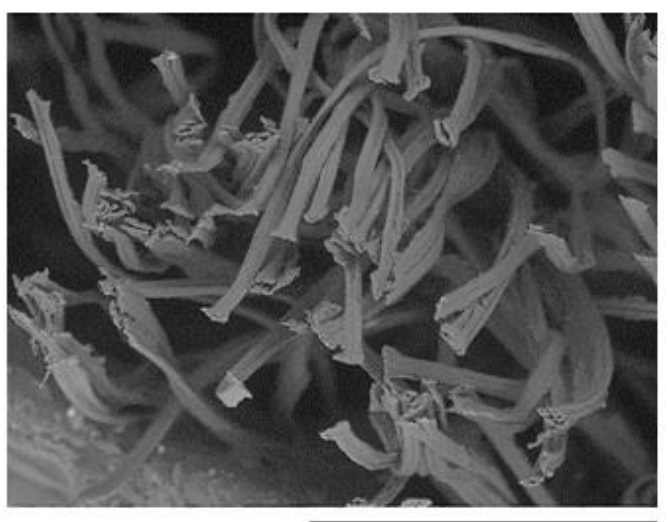

P100

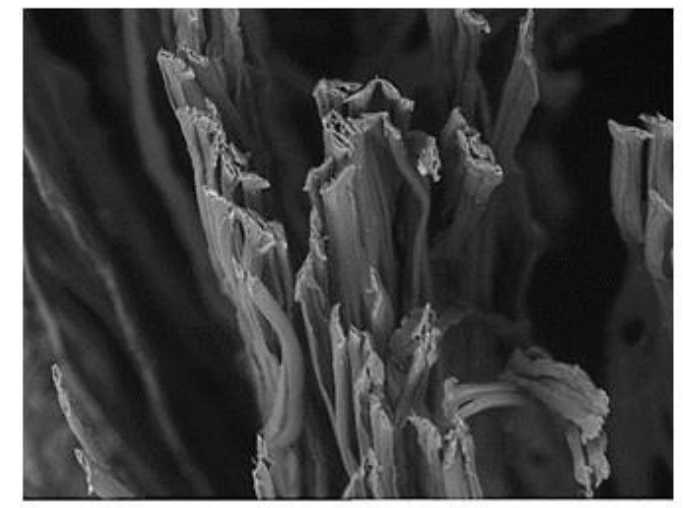

P200

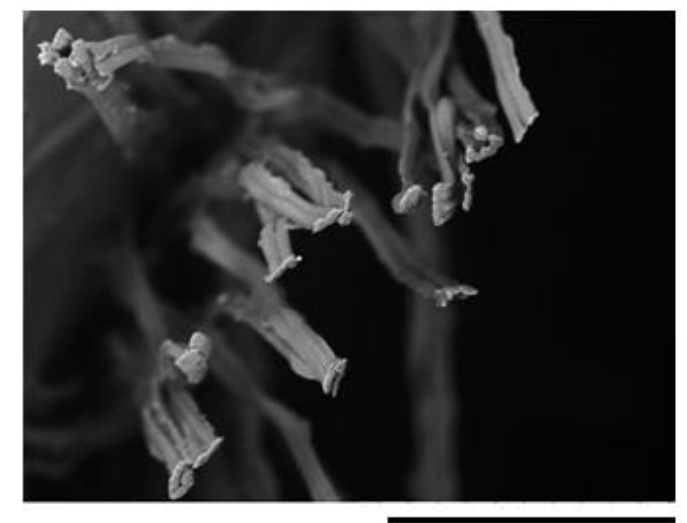

$300 \mathrm{~mm}$

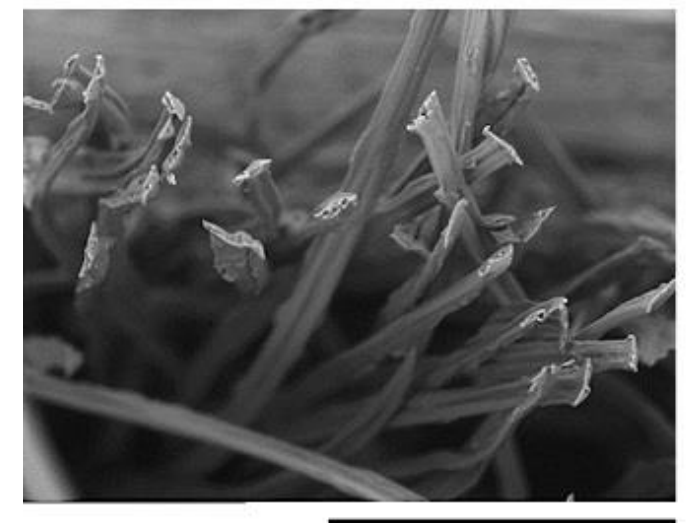

$\mathbf{3 0 0} \boldsymbol{\mu m}$

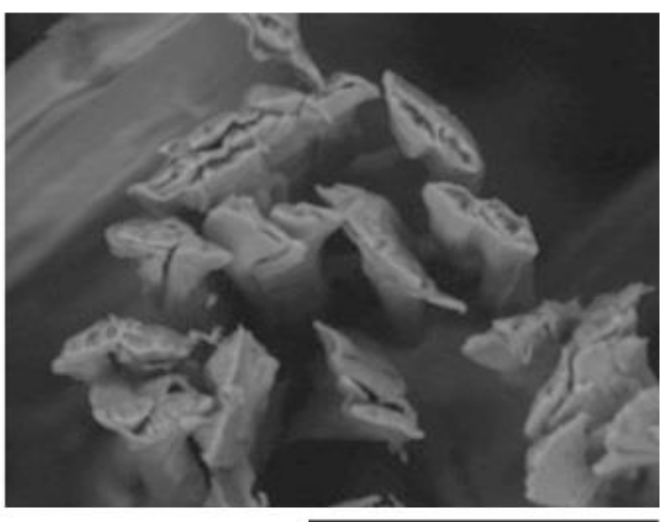

$100 \mu \mathrm{m}$

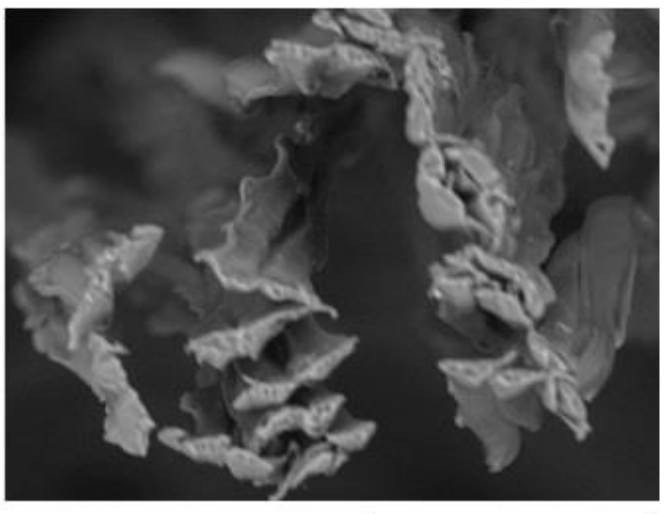

$120 \mathrm{~mm}$

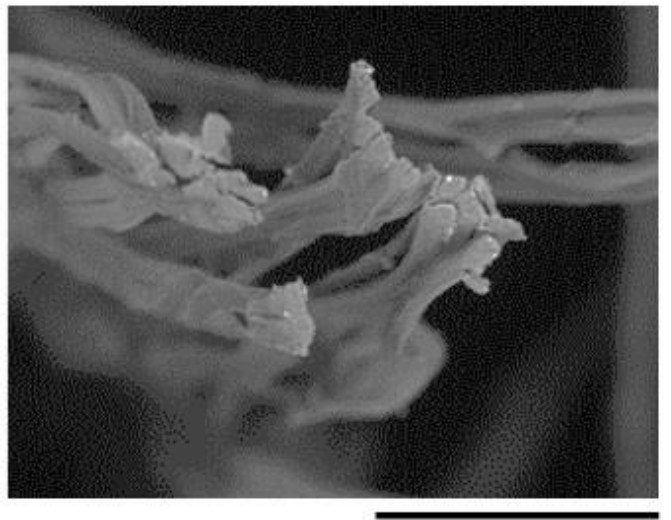

$120 \mathrm{~mm}$

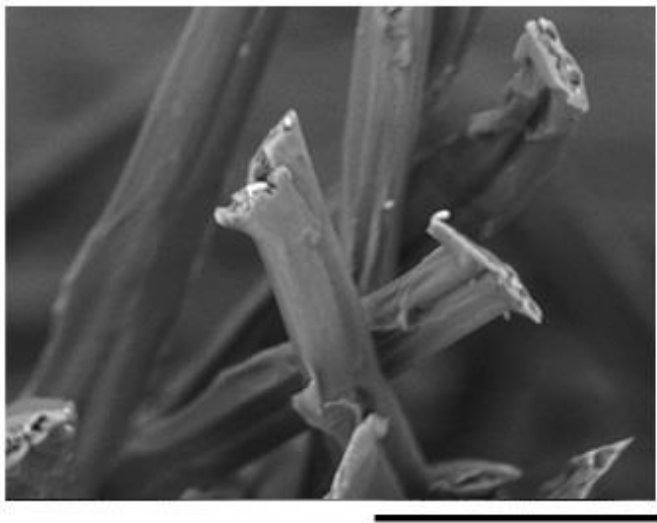

$90 \mathbf{~ m}$

Figure 4: Typical Scanning Electron Microscopy SEM micrographs of the cross section of the fracture zone of silk fibers after treatment Control, P100, P200 and P300 during Spring 2015 
The results indicate a reduction of mechanical behavior caused by the increase in the use of Pyraclostrobin. The treatment P100 showed an increase of stiffness. This increase may be correlated with the higher amount of Manganese found in plant nutrients analysis.

Treatments P200 and P300 reduced drastically the tensile strength. The same treatments were responsible for the higher mortality of silk worms and defected cocoons.

\section{Spring 2016}

\section{2 mineral content of mulberry leaves}

The application of pyraclostrobin resulted in lower nitrogen, phosphorus and potassium losses between 60 and 90 DAP and increase in calcium and magnesium, in comparison with control (Table 7). The treatments with pyraclostrobin has either reduced losses or increased the content for each micronutrient, in comparison with control (Table 8).

Table 7: Mulberry leaves macronutrients content $(\mathrm{g} / \mathrm{kg}$ of dry matter) and differences $(\Delta \%)$ between two evaluation periods of plants, in Spring 2016.

\begin{tabular}{|c|c|c|c|c|c|c|}
\hline \multicolumn{5}{|c|}{$\mathrm{N}(\mathrm{g} / \mathrm{kg})$} & \multicolumn{2}{|c|}{$\mathrm{P}(\mathrm{g} / \mathrm{kg})$} \\
\hline & $30 \mathrm{DBP}$ & $\begin{array}{c}\text { Pruning } \\
\text { day }\end{array}$ & $\Delta \%$ & $30 \mathrm{DBP}$ & $\begin{array}{c}\text { Pruning } \\
\text { day }\end{array}$ & $\Delta \%$ \\
\hline Control & 41.8 & 36.1 & -13.6 & 3.61 & 2.80 & -22.40 \\
\hline P100 & 40.5 & 37.2 & -8.15 & 3.54 & 2.89 & -18.36 \\
\hline P200 & 40.9 & 37.4 & -8.56 & 3.74 & 2.94 & -21.39 \\
\hline P300 & 40.1 & 37.0 & -7.73 & 3.80 & 3.01 & -20.79 \\
\hline \multicolumn{5}{|c|}{$\mathrm{K}(\mathrm{g} / \mathrm{kg})$} & \multicolumn{2}{|c|}{$\mathrm{Ca}(\mathrm{g} / \mathrm{kg})$} \\
\hline & $30 \mathrm{DBP}$ & $\begin{array}{c}\text { Pruning } \\
\text { day }\end{array}$ & $\Delta \%$ & $30 \mathrm{DBP}$ & $\begin{array}{c}\text { Pruning } \\
\text { day }\end{array}$ & $\Delta \%$ \\
\hline Control & 21.5 & 19.7 & -8.4 & 18.1 & 27.2 & +50.3 \\
\hline P100 & 21.8 & 19.9 & -8.7 & 17.5 & 26.9 & +53.7 \\
\hline P200 & 20.9 & 19.3 & -7.7 & 16.9 & 25.8 & +52.7 \\
\hline P300 & 21.2 & 20.0 & -5.7 & 17.7 & 28.0 & +58.2 \\
\hline \multicolumn{5}{|c|}{$\mathrm{Mg}(\mathrm{g} / \mathrm{kg})$} & \multicolumn{2}{|c|}{$\mathrm{S}(\mathrm{g} / \mathrm{kg})$} \\
\hline & $30 \mathrm{DBP}$ & $\begin{array}{c}\text { Pruning } \\
\text { day }\end{array}$ & $\Delta \%$ & 30 DBP & $\begin{array}{c}\text { Pruning } \\
\text { day }\end{array}$ & $\Delta \%$ \\
\hline Control & 2.8 & 3.1 & +10.7 & 2.4 & 2.3 & -4.2 \\
\hline P100 & 3.2 & 3.4 & +6.3 & 2.5 & 2.2 & -12 \\
\hline P200 & 3.3 & 3.6 & +9.1 & 2.3 & 2.2 & -4.5 \\
\hline P300 & 2.8 & 3.2 & +14.3 & 2.6 & 2.4 & -7.7 \\
\hline
\end{tabular}

DBP: Days before pruning of mulberry branches

Table 8: Mulberry leaves micronutrients content $(\mathrm{mg} / \mathrm{kg}$ of dry matter) and differences $(\Delta \%)$ between two evaluation periods of plants, in Spring 2016.

\begin{tabular}{lllllll}
\hline & \multicolumn{3}{c}{ B $(\mathrm{mg} / \mathrm{kg})$} & \multicolumn{3}{c}{$\mathrm{Cu}(\mathrm{mg} / \mathrm{kg})$} \\
& $60 \mathrm{DAP}$ & $90 \mathrm{DAP}$ & $\Delta \%$ & $60 \mathrm{DAP}$ & $90 \mathrm{DAP}$ & $\Delta \%$ \\
\hline Control & 35.8 & 51.4 & +43.6 & 8.0 & 8.2 & +2.5 \\
P100 & 38.1 & 55.7 & +46.2 & 8.0 & 8.5 & +6.3 \\
P200 & 37.6 & 55.0 & +46.3 & 8.5 & 8.7 & +2.4 \\
P300 & 39.0 & 55.7 & +42.8 & 8.2 & 9.0 & +9.8 \\
\hline
\end{tabular}




\begin{tabular}{lllllll}
\hline & \multicolumn{3}{c}{ Fe $(\mathrm{mg} / \mathrm{kg})$} & \multicolumn{3}{c}{ Mn $(\mathrm{mg} / \mathrm{kg})$} \\
& 60 DAP & 90 DAP & $\Delta \%$ & 60 DAP & 90 DAP & $\Delta \%$ \\
\hline Control & 164.5 & 119.8 & -27.2 & 37.2 & 41.0 & +10.2 \\
P100 & 148.0 & 110.4 & -25.4 & 36.7 & 42.9 & +16.9 \\
P200 & 171.5 & 130.3 & -24.0 & 41.9 & 51.5 & +22.9 \\
P300 & 159.0 & 138.2 & -20.8 & 38.0 & 45.4 & +19.5 \\
\hline
\end{tabular}

\subsubsection{Mulberry leaves consumption, silkworm mortality and cocoon production}

The use of pyraclostrobin only at 60 DAP did not change the amount of food consumed and the mortality of caterpillars in the Spring of $2016(\mathrm{P}>0.20)$ (Table 9). The 30-day interval between application and leaf delivery was sufficient to reduce the effect on mortality of caterpillars. In the Spring of 2015, with two applications of pyraclostrobin (60 and 75 DAP), mortality was higher as higher doses of pyraclostrobin were used (Table 3).

Table 9: Consumption in grams (g) of dry matter of mulberry leaves per caterpillar in the fifth instar and mortality rate (\%) in the Spring of 2016.

\begin{tabular}{lll}
\hline Treatments & Consumption $(\mathbf{g})$ & Mortality $(\%)$ \\
\hline Control & $5.84 \pm 1.24$ & $4.01 \pm 1.50$ \\
P100 & $5.21 \pm 1.87$ & $6.02 \pm 2.04$ \\
P200 & $5.55 \pm 1.01$ & $5.22 \pm 1.57$ \\
P300 & $5.47 \pm 1.45$ & $5.89 \pm 1.67$ \\
\hline
\end{tabular}

In Spring of 2016, the heavier cocoons and cocoon shells were obtained when the caterpillars received leaves not treated with pyraclostrobin, followed by caterpillars fed leaves from plants treated with 300, 200 and $100 \mathrm{~g} \mathrm{ha}^{-1}$ of pyra- $^{-}$ clostrobin (Table 10). The values of NSC for the cocoons corresponding to the treatment P300 are below satisfactory values for the industry [2]. The higher the dose of pyraclostrobin used, the greater the percentage obtained from defective cocoons.

Table 10: Weight of cocoons and cocoon shells (g), crude silk content (CSC,\%), net silk content (NSC,\%) and percentage of defective cocoons obtained from caterpillars fed on leaves treated with pyraclostrobin in the Spring of 2016.

\begin{tabular}{cccccc}
\hline Treatments & Cocoons $\mathbf{( g )}$ & $\begin{array}{c}\text { Cocoon shells } \\
\mathbf{( g )}\end{array}$ & $\begin{array}{c}\text { CSC } \\
\mathbf{( \% )}\end{array}$ & $\begin{array}{c}\text { NSC } \\
\mathbf{( \% )}\end{array}$ & $\begin{array}{c}\text { Declassified } \\
\text { cocoons (\%) }\end{array}$ \\
\hline Control & $1.73 \pm 0.06 \mathrm{a} 1$ & $0.36 \pm 0.01 \mathrm{a}$ & $20.90 \pm 1.36$ & $15.88 \pm 1.03$ & 4.21 \\
P100 & $1.41 \pm 0.09 \mathrm{~d}$ & $0.28 \pm 0.02 \mathrm{~d}$ & $19.91 \pm 1.11$ & $15.13 \pm 0.84$ & 4.75 \\
P200 & $1.54 \pm 0.14 \mathrm{c}$ & $0.31 \pm 0.02 \mathrm{c}$ & $20.15 \pm 1.05$ & $15.31 \pm 0.80$ & 5.28 \\
P300 & $1.61 \pm 0.14 \mathrm{~b}$ & $0.33 \pm 0.02 \mathrm{~b}$ & $20.52 \pm 1.28$ & $15.59 \pm 0.97$ & 6.12 \\
\hline
\end{tabular}

\footnotetext{
${ }^{1}$ Means followed by different letters in the same column differ by the Tukey test (5\%).
}

The X-ray diffractograms of silk fiber threads in different conditions and the calculated results of crystallinity are presented in Figure 5. Crystallinity and crystal size values are presented in Table 11. The three peaks denoted in the diffractogram represent Silk II, whereas the smooth peak located between peaks two and three corresponds to Silk I. The tendency of silk threads is to replace Silk I for Silk II in the spinning process. This way, Silk I could be either all converted to Silk II, or its small peak merged on the amorphous halo, which could difficult its visualization. Thus, the difference between treatments regarding Silk I is difficult to assess due to overlapping of the neighboring peaks. The application of pyraclostrobin and the change in minerals intake by the silkworms seems to have a positive effect in the Spring of 2016 in comparison to 2015. In 2016, crystallinity values have remained close to control. 


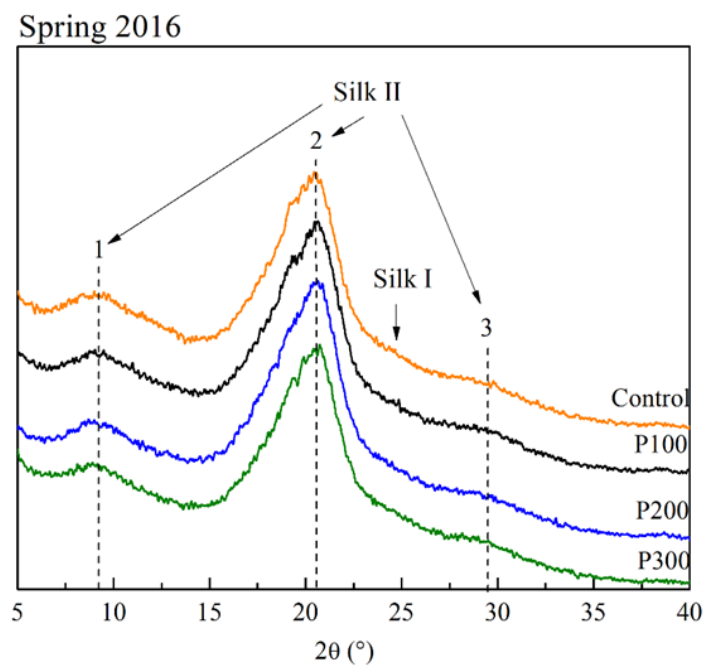

Figure 5: X-ray diffractograms of silk fibers thread produced Spring of 2016, in different conditions. Peaks 1, 2 and 3 are related to Silk II, while the smooth peak between peaks 2 and 3 corresponds to Silk I.

Table 11: Crystallinity parameters determined from the X-ray diffractograms of silk fiber in different conditions at Spring 2016

\begin{tabular}{cccc}
\hline Fibers/Treatment & Crystallinity (\%) & Peak & Crystal size (nm) \\
\hline \multirow{2}{*}{ Control } & 66.0 & 1 & 2.1 \\
& & 2 & 4.0 \\
P100 & \multirow{2}{*}{65.2} & 1 & 2.1 \\
& & 2 & 3.8 \\
P200 & 67.1 & 1 & 2.3 \\
& & 2 & 4.1 \\
P300 & 66.7 & 1 & 2.3 \\
& & 2 & 3.3 \\
\hline
\end{tabular}

The comparison between the typical curves obtained by tensile test of silk fibers from Spring of 2016 is presented in Figure 6. Table 12 summarizes the results for all mechanical tests. Comparing the used treatments, it is possible to observe that the treatments P100, P200 and P300 have promoted a decrease in the ultimate tensile strength, when compared to the control. The same reduction was observed to tensile strain (Table 12). Despite the reduction, all treatments analyzed in 2016 have had a better result compared to 2015. This may be due to the fact that the intake of important minerals to form beta-sheet fibroin, such as $\mathrm{Cu}, \mathrm{Ca}$ and $\mathrm{Mn}[\underline{6}, \underline{14}, \underline{28}]$, has remained close to values of the control. It may ease the spinning of better-formed silk threads that can present a better reinforcement feature.

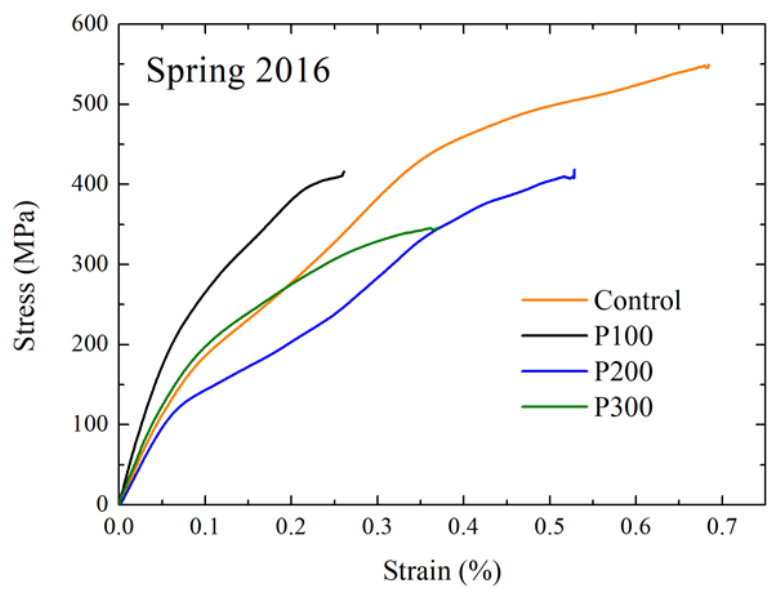

Figure 6: Typical curve from silk fibers of Spring 2016 with P100, P200, P300 and Control. 
This behavior is highly influenced by the chemical composition of the coir fiber and fiber morphology. Regarding the tensile behavior, FERREIRA et al. [26] believe that the nonlinear stress-strain portion prior to fracture is due to the delamination of one or more fiber-cells due to the weakening of the lignin and hemicellulose during the loading process. A similar tensile behavior is also presented by [11].

Regarding silk fibers, microstructural analysis does not indicate the same behavior observed for coir fibers. However, note that after tensile test, a few samples presented a "twisted" shape (Figure 7). This may indicate some structure modification during the test that modify silk fiber stiffness. The change in fiber structure is being investigated in a parallel research.

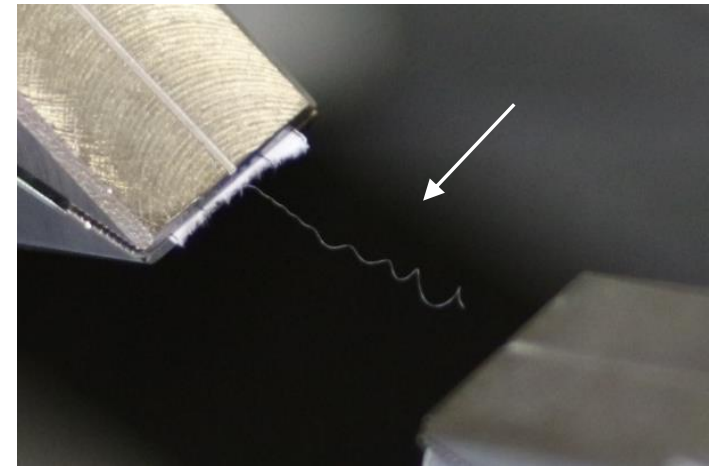

(a)

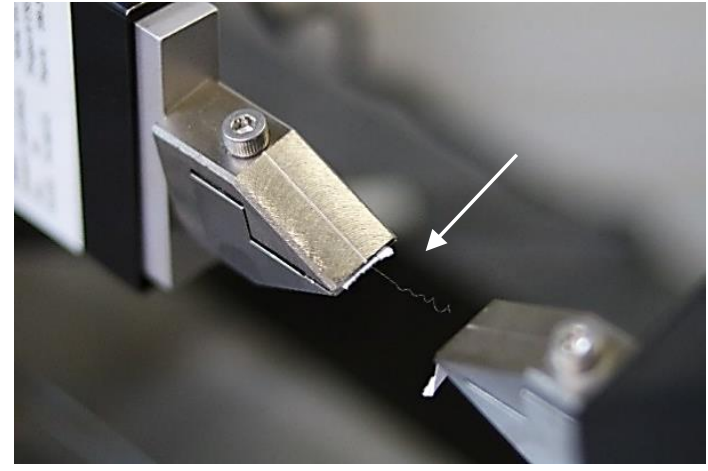

(b)

Figure 7: Tensile test machine: (a) view of tensile test grips and post-fracture silk fiber presenting a twisted shape

Table 12: Mechanical properties of natural fibers on tensile strength tested on Spring 2016

\begin{tabular}{lccccc}
\hline Fibers & & Control & P100 & P200 & P300 \\
\hline Strain & $(\%)$ & $0.75 \pm 0.46$ & $0.35 \pm 0.16$ & $0.46 \pm 0.14$ & $0.54 \pm 0.32$ \\
Tensile strength & $(\mathrm{MPa})$ & $506.91 \pm 142.39$ & $476.17 \pm 189.00$ & $446.48 \pm 131.61$ & $463.39 \pm 173.00$ \\
Young modulus I & $(\mathrm{GPa})$ & $5.8 \pm 1.2$ & $5.4 \pm 1.1$ & $4.9 \pm 0.7$ & $5.1 \pm 0.3$ \\
Young modulus II & $(\mathrm{GPa})$ & $4.4 \pm 0.5$ & $4.8 \pm 0.8$ & $4.9 \pm 0.5$ & $4.6 \pm 0.2$ \\
Young modulus III & $(\mathrm{GPa})$ & $3.2 \pm 0.8$ & $4.5 \pm 1.1$ & $4.7 \pm 0.4$ & $4.2 \pm 1.2$ \\
Resilience & $(\mathrm{MPa})$ & $0.90 \pm 0.48$ & $0.66 \pm 0.35$ & $0.59 \pm 0.17$ & $0.85 \pm 0.37$ \\
Toughness & $(\mathrm{J} / \mathrm{m} 2)$ & $52.71 \pm 40.18$ & $18.02 \pm 12.45$ & $22.44 \pm 14.52$ & $33.79 \pm 29.29$ \\
\hline
\end{tabular}

The results indicate a similar behavior as observed in Spring 2015. The use of Pyraclostrobin promoted a decrease on tensile strength and stiffness. Silk fibers after treatment with $100 \mathrm{~g} . \mathrm{ha}^{-1}$ of Pyraclostrobin showed an increase of stiffness as observed in 2015. Differently for this case, the increase is not correlated with the higher amount of Manganese found in plant nutrients analysis. According to XRD results the crystallinity index for the samples with $100 \mathrm{~g} \cdot \mathrm{ha}^{-1}$ were lower in comparison to the other treatments, including control. Tensile strength has been decreased for all treatments by the use of pyraclostrobin in 2016, although not as drastically as observed for 2015 (see Table 7). That may have happened due the double application of the fungicide during 2015. This can be justified by the silkworm mortality over 10 times higher, in comparison to 2016.

The rupture mode of all tested silk fibers is presented in Figure 8. It is possible to observe that all fibers presented the same rupture mode. Regarding the fiber cross-section, no significant difference in cross-section area was observed. 


\section{Control}

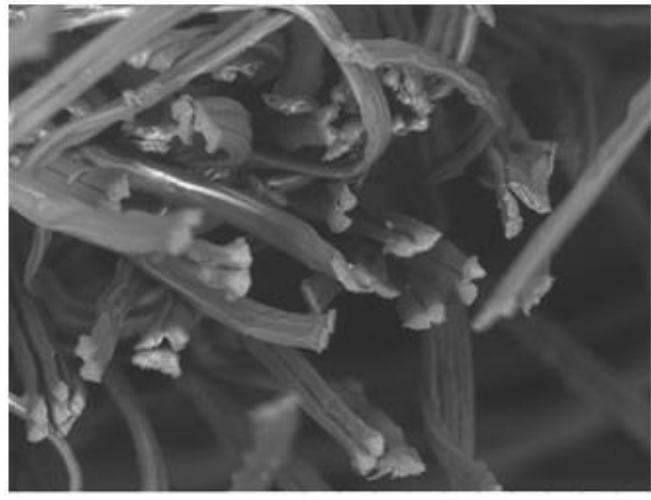

P100

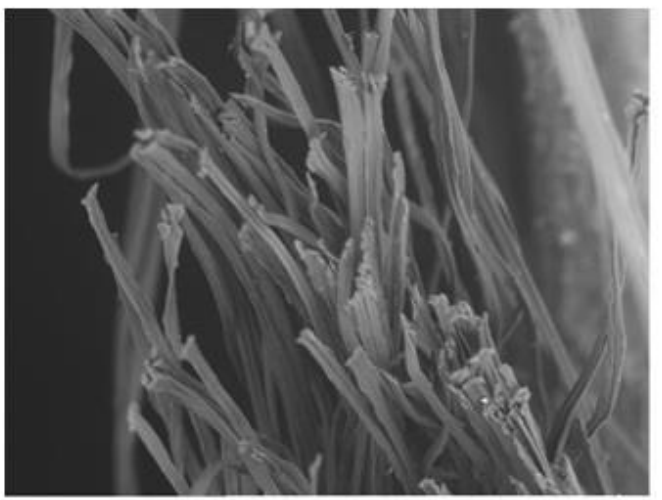

P200

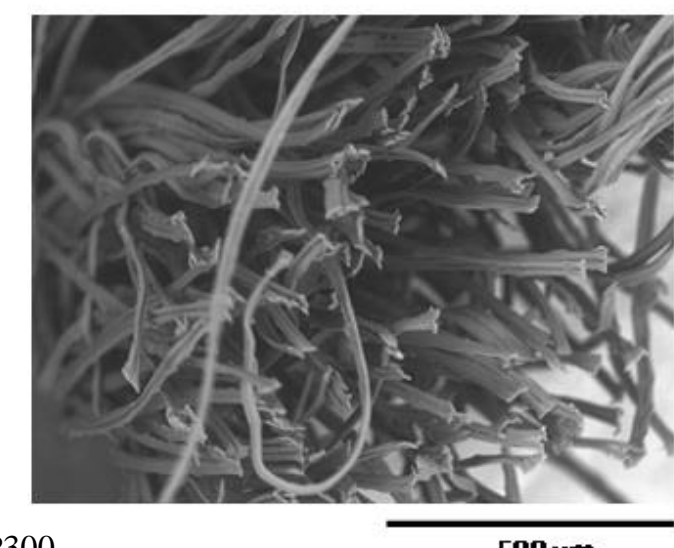

P300

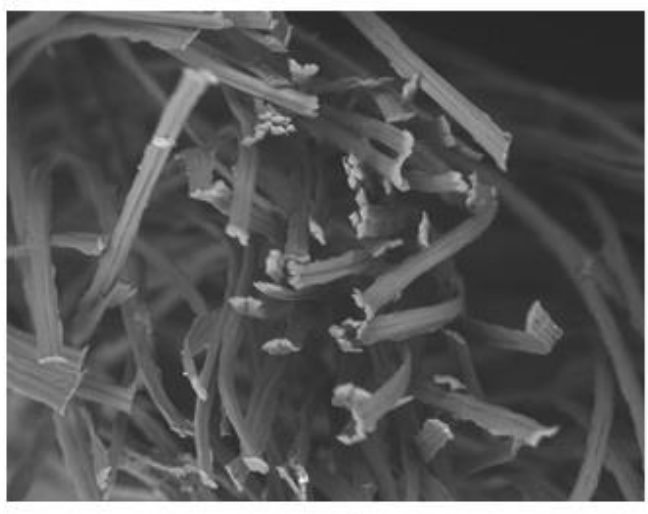

$400 \mu \mathrm{m}$

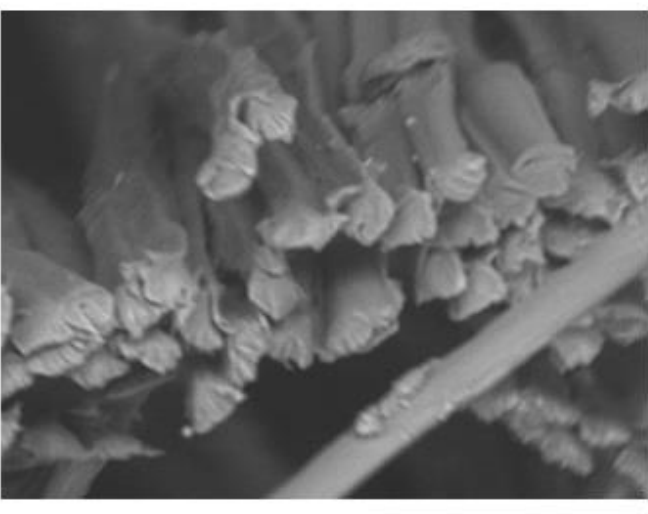

$90 \mu \mathrm{m}$

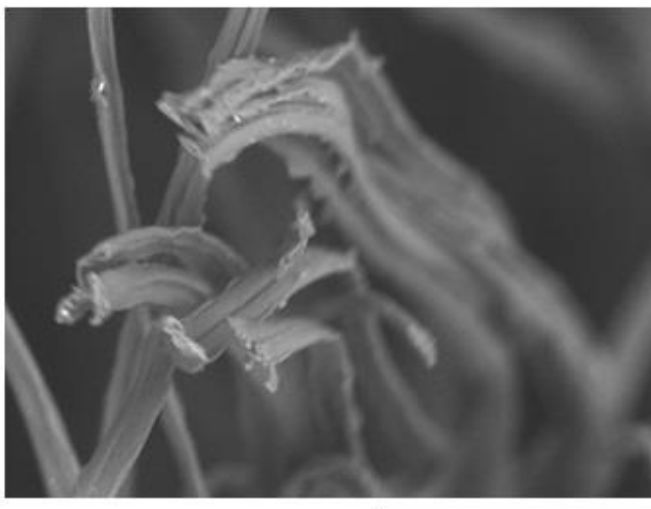

$125 \mu \mathrm{m}$

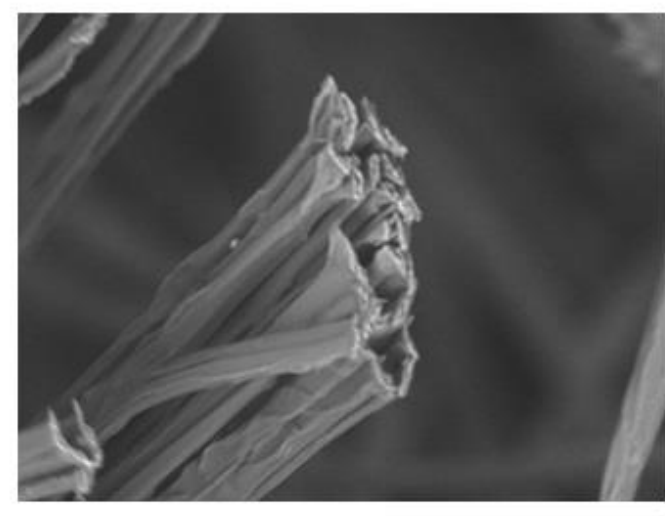

$150 \mathrm{~mm}$

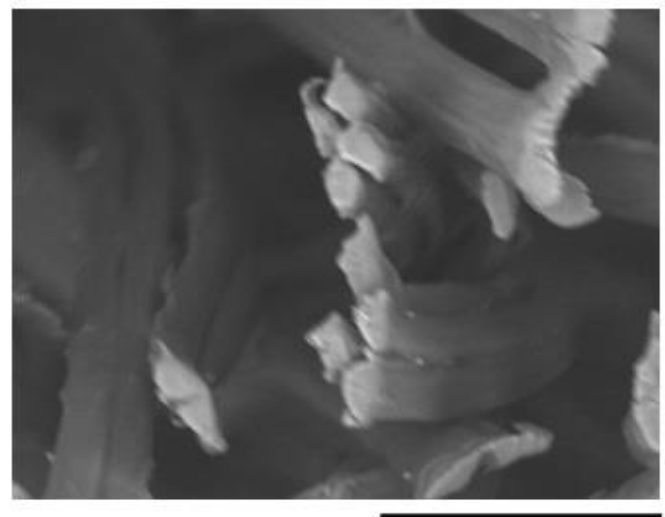

$200 \mathrm{~m}$

Figure 8: Typical Scanning Electron Microscopy SEM micrographs of the cross section of the fracture zone of silk fibers after treatment Control, P100, P200 and P300 during Spring 2016 
The tensile tests results indicate that in both studied cases the use of pyraclostrobin reduces the mechanical behavior. Higher amounts of pyraclostrobin have decreased the ultimate tensile strength and the strain capacity of the silk fibers (Tables 6 and 12). Even with only one application of pyraclostrobin resulted in lighter cocoons. Pyraclostrobin impaired silk tensile. It was observed that the use of pyraclostobin drastically reduces silk mechanical behavior, even in small volumes.

Even with a nutritional increase caused by the application of the fungicide to the mulberry leaves, the use of pyraclostrobin implied in the reduction of the quality of the cocoons and silk threads. The periods of 15 and 30 days between the application of the fungicide and the offering of the treated leaves to the caterpillars were not enough to mitigate the harm inherent to the pesticide, even if it is an insect and not a fungus. In a study that sought to evaluate whether pyraclostrobin interferes with the mitochondrial bioenergetics of silkworm caterpillars, it was found that at doses of $200 \mathrm{~g}$ $\mathrm{ha}^{-1}$, piraclostrobin impaired the mitochondrial bioenergetics of silkworms [23] .

\section{CONCLUSION}

The following conclusions can be drawn:

- The present research indicates that the use of pyraclostrobin may provide better nutritional quality for mulberry leaves;

- The use of mulberry leaves treated twice with pyraclostrobin promotes an increase on caterpillar mortality rates and their cocoons quality;

- The increase on pyraclostrobin concentration promotes a decrease on silk fibers mechanical performance, which can be observed on 2015 Spring results;

- In both studied years, the treatment P100 promoted an increase in Silk fiber stiffness, followed by a reduction on tensile strength of the fibers;

- The high caterpillar mortality rates and the decrease in quality of both cocoons and silk fibers, makes pyraclostrobin use impracticable.

\section{ACKNOWLEDGEMENTS}

The authors would like to thank Fundação de Amparo à Pesquisa do Estado de São Paulo (FAPESP - process n. 2014/25673-0), Coordenação de Aperfeiçoamento de Pessoal de Nível Superior (CAPES), Conselho Nacional de Desenvolvimento Científico e Tecnológico $(\mathrm{CNPq})$ and Fundação de Amparo à Pesquisa do Estado de Minas Gerais (FAPEMIG). The authors would like to thank the technical support of NUMATS/UFRJ and Centro de Tecnologia Mineral CETEM.

\section{REFERENCES}

[1] SABBAG, O.J., NICODEMO, D., OLIVEIRA, J.E.M. Custos e viabilidade econômica da produção de casulos do bicho-da-seda, https://doi.org/10.1590/S1983-40632013000200004. Pesqui. Agropecu. Trop. v. 43, pp. 187-194. 2013.

[2] R.T. et al, Sericicultura: Uma Promissora Exploração Agropecuária 2a Edição, 2009.

[3] K. PUROHIT, K.P, Influence of various agronomical practices in India on the leaf quality in mulberry, a review, Sericologia. v. 36, pp. 27-41, 1996.

[4] CHEN, R.X., Contrastive research on the waterproof and dustproof mechanism of wild silkworm silk and domestic silkworm silk, https://doi.org/10.1590/S1517-70762014000400011. Rev. Mater. v. 19, pp. 395-399, 2014.

[5] OKAMOTO, F., RODELLA, R.A. Características morfo-anatômicas e bromatológicas de folhas de amoreira em relação às preferências do bicho-da-seda, https://doi.org/10.1361/154770306X97687. Pesqui. Agropecu. Bras. v. 41, pp. 195-203, 2006.

[6] ZHOU, L., CHEN, X., SHAO, Z., et al. Copper in the silk formation process of Bombyx mori silkworm, https://doi.org/10.1016/S0014-5793(03)01184-0. FEBS Lett. 554, pp. 337-341, 2003.

[7] TANAKA, K., UDA, Y., ONO, Y. et al., Highly Selective Tuning of a Silkworm Olfactory Receptor to a Key Mulberry Leaf Volatile, https://doi.org/10.1016/j.cub.2009.04.035. Curr. Biol. v. 19, pp. 881-890, 2009

[8] POLYCARPO, G.V., SILVA, A.A.R., FRUCHI, V.M. Enriquecimento da dieta do bicho-da-seda com extrato hidrossolúvel de soja, https://doi.org/10.1590/S0103-84782012000900024. Ciência Rural. v. 42, pp. 1669-1674, 2012.

[9] NICODEMO, D., OLIVEIRA, J.E., SEDANO, A.A., et al., Tonoli, Impact of different silkworm dietary 
supplements on its silk performance, https://doi.org/10.1007/s10853-014-8355-4. J. Mater. Sci. v. 49, pp. 6302-6310, 2014.

[10] CAI, L., SHAO, H., HU, X., et al., Reinforced and Ultraviolet Resistant Silks from Silkworms Fed with Titanium Dioxide Nanoparticles, ACS Sustain. https://doi.org/10.1021/acssuschemeng.5b00749. Chem. Eng. v. 3, pp. 2551-2557, 2015.

[11] GUO, K., DONG, Z., ZHANG, Y., et al., Improved strength of silk fibers in Bombyx mori trimolters induced by an anti-juvenile hormone compound, Biochim. Biophys.

https://doi.org/10.1016/j.bbagen.2018.02.007. Acta - Gen. Subj. 1862, pp. 1148-1156, 2018.

[12] WANG, Q., WANG, C., ZHANG, M., et al., Feeding Single-Walled Carbon Nanotubes or Graphene to Silkworms for Reinforced Silk Fibers, https://doi.org/10.1021/acs.nanolett.6b03597. Nano Lett. 16, pp. 66956700. 2016

[13] WANG, J.-T., LI, L.-L, ZHANG, M.-Y, et al., Directly obtaining high strength silk fiber from silkworm by feeding carbon nanotubes, https://doi.org/10.1016/j.msec.2013.09.041. Mater. Sci. Eng. C. 34, pp. 417421, 2014.

[14] FERNANDES, J., NICODEMO, D., OLIVEIRA, J.E., et al. Enhanced silk performance by enriching the silkworm diet with bordeaux mixture, https://doi.org/10.1007/s10853-016-0559-3. J. Mater. Sci. v. 52, pp. 2684-2693, 2017.

[15] KÖHLE, H., GROSSMANN, K., JABS, T., et al., Physiological effects of the strobilurin fungicide F 500 on plants, in: Mod. Fungic. Antifung. Compd. III, 3rd ed., Agroconcept GmbH, Bonn, Germany, 2003.

[16] DIMMOCK, J.P.R.E., GOODING, M.J., The effects of fungicides on rate and duration of grain filling in winter wheat in relation to maintenance of flag leaf green area, https://doi.org/10.1017/S0021859601001666. J. Agric. Sci. v. 138, pp. 1-16, 2002.

[17] LAZAR, T., TAIZ, L., ZEIGER, E. Plant physiology. 3rd edn., https://doi.org/10.1093/aob/mcg079. Ann. Bot. v. 91, pp. 750-751, 2003.

[18] FAGAN, E.B., DOURADO NETO, D., VIVIAN, R., et al., Efeito da aplicação de piraclostrobina na taxa fotossintética, respiração, atividade da enzima nitrato redutase e produtividade de grãos de soja, https://doi.org/10.1590/S0006-87052010000400001. Bragantia. v. 69, pp. 771-777, 2010.

[19] MALAVOLTA, E., VITTI, S.A., OLIVEIRA, G.C. Avaliação do estado nutricional das plantas: princípios e aplicações, 2nd ed., Piracicaba, 1997.

[20] A.O.A.C, Official methods of analysis of the Association of Official Analytical Chemists, Virginia, USA, 1990.

[21] SILVA, D.J., QUEIROZ, A.C., Análise de alimentos: métodos químicos e biológicos., 3rd ed., Viçosa, 2006.

[22] KALRA, Y., Handbook and reference methods for plants analysis, New York, 1998.

[23] NICODEMO, D., MINGATTO, F.E., CARVALHO, A., et al., Pyraclostrobin Impairs Energetic Mitochondrial Metabolism and Productive Performance of Silkworm (Lepidoptera: Bombycidae)

Caterpillars, https://doi.org/10.1093/jee/toy060. J. Econ. Entomol. v. 111, pp. 1369-1375. 2018

[24] HANADA, Y., WATANABE, J.K., Manual de criação do bicho-da-seda, Curitiba, 1986.

[25] A. International, ASTM C1257-14, Standard Test Method for Tensile Strength and Young's Modulus of Fibers, PA, 2014.

[26] FERREIRA, S.R., SILVA, A.M., SOUZA JR, F.G., et al. Effect of Polyaniline and H2O2 Surface Modification on the Tensile Behavior and Chemical Properties of Coir Fibers, https://doi.org/10.1166/jbmb.2014.1478. J. Biobased Mater. Bioenergy. v. 8, pp. 578-586, 2014.

[27] VEPARI, C., KAPLAN, D.L. Silk as a biomaterial, Prog. Polym. Sci. 32 (2007) 991-1007. https://doi.org/10.1016/j.progpolymsci.2007.05.013.

[28] BIN DENG, Y., JI, D., SUN, P.C., et al., The role of Mn(II) in silk fibroin based on EPR and NMR spectroscopy, https://doi.org/10.1080/00387010.2010.491104. Spectrosc. Lett. v. 44, pp. 176-185, 2011.

\section{ORCID}

Saulo Rocha Ferreira

Luiz Eduardo Silva

Renata Daniel dos Santos
https://orcid.org/0000-0002-4048-907X

https://orcid.org/0000-0003-0196-6643

https://orcid.org/0000-0001-8109-1642 
Romildo Toledo Filho

Otavio Fonseca Martins Gomes

Gustavo Henrique Denzin Tonoli

Daniel Nicodemo https://orcid.org/0000-0001-5867-4452

https://orcid.org/0000-0002-6472-3625

https://orcid.org/0000-0002-6502-8974

https://orcid.org/0000-0001-6594-5791 